\title{
Article \\ Changes in the Potential Distribution of Vanilla planifolia Andrews under Different Climate Change Projections in Mexico
}

\author{
Samaria Armenta-Montero ${ }^{1}$, Rebeca Menchaca-García ${ }^{1}$, Araceli Pérez-Silva ${ }^{2}$ and Noé Velázquez-Rosas ${ }^{1, *(D)}$ \\ 1 Centro de Investigaciones Tropicales, Universidad Veracruzana, Xalapa 91000, Mexico; \\ samaria.am@gmail.com (S.A.-M.); rmenchaca@uv.mx (R.M.-G.) \\ 2 Departamento de Ingeniería Química y Bioquímica, Instituto Tecnológico de México, Campus Tuxtepec, \\ Tuxtepec 68350, Mexico; araceli.ps@tecnm.tuxtepec.mx \\ * Correspondence: novelazquez@uv.mx
}

Citation: Armenta-Montero, S.; Menchaca-García, R.; Pérez-Silva, A.; Velázquez-Rosas, N. Changes in the Potential Distribution of Vanilla planifolia Andrews under Different Climate Change Projections in

Mexico. Sustainability 2022, 14, 2881. https://doi.org/10.3390/su14052881 Academic Editor: Roberto Mancinelli

Received: 21 January 2022 Accepted: 21 February 2022 Published: 1 March 2022

Publisher's Note: MDPI stays neutral with regard to jurisdictional claims in published maps and institutional affiliations.

Copyright: (C) 2022 by the authors. Licensee MDPI, Basel, Switzerland. This article is an open access article distributed under the terms and conditions of the Creative Commons Attribution (CC BY) license (https:// creativecommons.org/licenses/by/ $4.0 /)$.

\begin{abstract}
Vanilla planifolia is the most widely cultivated species for obtaining natural vanilla. In Mexico, vanilla production has decreased due to negative effects of climate change. We evaluate the current, potential, and future of vanilla cultivation areas in Mexico using bioclimatic models with distinct climate change scenarios (intermediate emissions, temperature rise of 1.1 to $2.6^{\circ} \mathrm{C}$, and high emissions from 2.6 to $4.8^{\circ} \mathrm{C}$, to 2050 and 2070), in order to understand the magnitude of future distribution changes and propose future management strategies. We found that the areas with greatest potential for establishment of $V$. planifolia are northern Veracruz state bordering the state of Puebla (the Totonacapan region) and northeast Oaxaca state. In the models, the most relevant environmental variable were mean temperature and precipitation of the driest quarter. The average projections for 2050 and 2070 show a progressive reduction in the potential area for the species $(-1.6$ and $-17.3 \%$ ). However, the Totonacapan region maintains the largest ideal cultivation area, while that of northeast Oaxaca is reduced by $50 \%$. These results show the need to redesign the strategies of agricultural production of vanilla, through sustainable and climate-smart agricultural production strategies as well as a national strategy for conservation of genetic diversity.
\end{abstract}

Keywords: potential distribution; climate change scenarios; sustainable management; traditional vanilla beans

\section{Introduction}

Rising temperature and changes in precipitation patterns (more pronounced periods of drought and torrential rain) caused by climate change represent an enormous challenge for agriculture worldwide [1,2]. Although the negative effects on agriculture vary across the world, tropical and subtropical zones will be the most affected in the medium term by rising temperatures during the growing season, which could reach the greatest extremes registered between 1900 and 2006 [3]. This increase in temperature may cause water and heat stress in crops, reduce productivity, and increase the incidence of pests and pathogens [4]. Furthermore, extreme droughts, floods, and soil erosion cause crop loss [5]. As a result, the production zones for different crops are at risk and are projected to decline in various parts of the world [6-8].

One of the crops most sensitive to temperature changes is vanilla [9]. Vanilla planifolia Andrews is an aromatic species used in the food, pharmaceutical, and soft drink industries [10], and is the most cultivated species for obtaining vanillin [11]. It is naturally found in tropical areas and its cultivation is considered to have originated in Mexico and Mesoamerica [11,12]. It is distributed at an altitudinal range from 0 to $1650 \mathrm{~m}$ asl $[12,13]$, although it is recognized that the most favorable altitude range for its cultivation is from 0 to $600 \mathrm{~m}$ asl [14]. V. planifolia requires an average annual rainfall of $1500 \mathrm{~mm}$ and average temperatures between 21 and $27{ }^{\circ} \mathrm{C}$ [14]. Currently, in Mexico it is subject to special protection in accordance with Mexican regulations (NOM-059-SEMARNAT-2019). It is 
also listed as an endangered species under the Convention on International Trade in Endangered Species of Wild Flora and Fauna [15] and endangered under criteria B2ab (II, V) for the International Union for Conservation of Nature Red List [16]. This status is due to the species' limited genetic diversity in cultivation areas, since dispersal for cultivation occurred vegetatively $[11,16]$. Wild vanilla populations have also declined due to the destruction of natural habitats [11,12].

Globally, the main vanilla producers are Madagascar and Indonesia. Mexico ranked third in 2019 , with $6.5 \%$ of global production, that is, $522 \mathrm{t}^{1}$ [17]. However, vanilla production has been reduced by the influence of diseases and premature fruit drop, factors associated with periods of prolonged droughts and high temperatures [18,19]. Vanilla cultivation is considered especially sensitive to climate change because its genetic variation in crops is very low $[12,13,20,21]$; therefore, it has a limited response capacity to the proliferation of diseases, prolonged drought events, and thermal stress [18,22].

In Mexico and Latin America, vanilla producers have initiated a series of actions to face the challenges of climate change, including the implementation of irrigation systems and technified production systems (nurseries, shade houses), as well as the adoption of agroecological management strategies, rescue of traditional production systems, and changes in cultivation areas [23-25]. This last action aims to expand the cultivation area to regions with more favorable temperature and humidity conditions. Although this action can be an opportunity for the expansion of megathermal species, it can also generate problems in ecosystem processes, such as loss of biodiversity and carbon storage, hydrological imbalances, generation of new pests and diseases or their resistance, as well as significant economic losses [4]. The initiatives taken by producers in Latin America to change cultivation areas are not based on studies analyzing changing climate patterns, their effects on distribution of cultivation areas, and bioclimatic requirements of the cultivated species [4], as is the case for vanilla. For this reason, it is essential to use tools that allow the evaluation of current and future crop distribution under different climatic conditions.

Species distribution models are tools that allow evaluation of the magnitude of potential effects on species presence and potential distribution in response to climate change $[26,27]$. They also allow rapid analysis and identification of key relationships between environmental variables and species. Species distribution modeling is based on bioclimatic variables [28], because these limits the distribution of species, variables such as temperature and the presence of water [29], such as WorldClim [30] or Chelsa [31]. These models are very robust tools to assess species distributions on a wide variety of spatial and temporal scales, since any biovariable can be mapped, their assumptions are explicit, and their results are repeatable. Furthermore, they are not affected by reference areas, and they assign probabilities to points in space [27]. Commonly used species distribution models include BIOCLIM (e.g., [32]), GARP (Genetic Algorithm for Rule-set Prediction; e.g., [33]), and MAXENT (maximum entropy; [34]). Models are very important tools to formulate, design, and plan measures to adapt or mitigate the negative effects of climate change on various crops $[4,6]$.

In this study we evaluate the current and potential future distribution of vanilla cultivation areas in Mexico. We use bioclimatic projection models with different climate change scenarios to understand the magnitude of future distribution changes, implications for the design of crop management and mitigation strategies in response to the challenges posed by climate change, as well as the repercussions for conservation of natural populations of this species.

\section{Materials and Methods}

\subsection{Species Occurrence Data}

A database was built for the distribution of vanilla (V. planifolia) crops and collection sites in Mexico based on review of data records from the World Biodiversity Information Network (REMIB for its acronym in Spanish) of the Comisión Nacional para el Conocimiento y Uso de la Biodiversidad (CONABIO), Tropicos database of the Missouri 
Botanical Garden, vanilla production sites registered by the company Vanilla and Spice, S. A. de C.V. and producers from the Papantla region of Veracruz and northern Puebla, Mexico. The authors registered 186 locations from nine states of the country and verified their existence using Google Earth and the locality database of the Instituto Nacional de Estadística y Geografía (INEGI) [35], obtaining a final total of 166 localities. Data on the presence of $V$. planifolia were analyzed using ESRI ArcGIS v.10.2.2 software, selecting all of the points within a $\sim 1 \mathrm{~km}^{2}$ area (to fit the pixel size of the environmental variables). This was done to reduce the overlap of records; therefore, only 100 points were used for the analysis with the program MaxEnt v. 3.4.1.

\subsection{Potential Distribution}

The distribution area of $V$. planifolia was determined using the BAM model of Soberón and Peterson [36], which indicates the relationship between biotic (B) and abiotic (A) factors and the mobility $(\mathrm{M})$ of the species within a geographic area. To determine this " $\mathrm{M}$ " the ecoregion map was used [37], based on the species records. V. planifolia was found to occupy southeastern Mexico including the ecoregions of dry, humid, pine-oak, and montane forests of the Sierra de Los Tuxtlas of Veracruz; montane and pine-oak forests of Oaxaca; humid and dry forests of Yucatán Peninsula; as well as the Pantanos de Centla ecoregion; and the Mesoamerican Gulf-Caribbean mangroves (Figure 1).

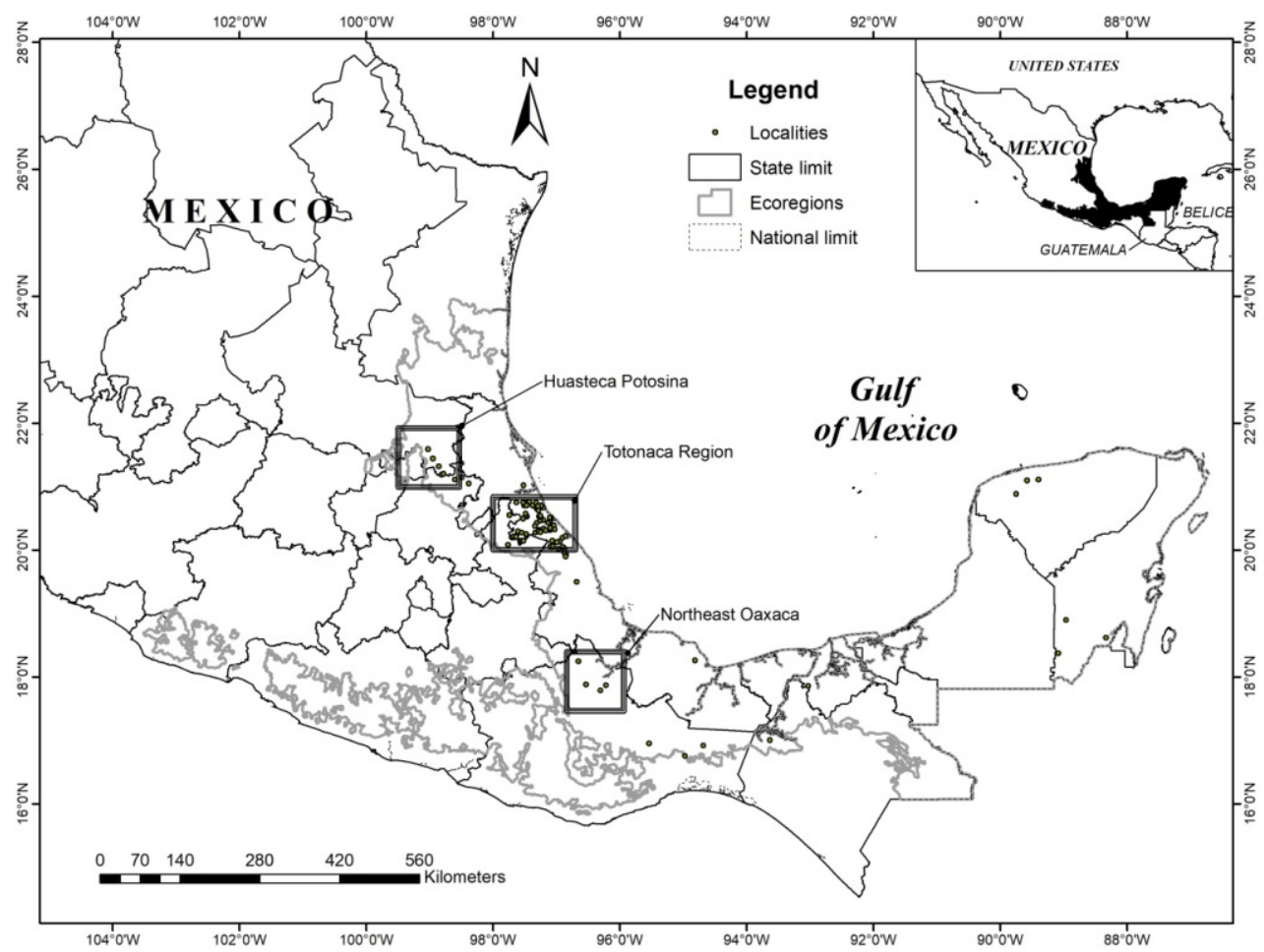

Figure 1. Study area determined by the ecoregions of Olson et al. [37] and the location of the Vanilla planifolia crops in Mexico.

The following cartography and variables were used: (i) global canopy cover [38], (ii) land use and vegetation [39], (iii) soil types [40], (iv) soil moisture regime [41], and (v) 20 environmental variables of WorldClim v.1.4 [30]. These climate databases have a resolution of $\sim 1 \mathrm{~km}^{2}$. Later the package $\mathrm{R}$ v. 3.5.1 was used to carry out a collinearity test of the variables in order to eliminate those that were more correlated [42]. In the end, 17 variables were used to model the potential distribution (Table 1). 
Table 1. Bioclimatic and environmental variables used by the Maxent model to project the potential distribution of Vanilla planifolia in México.

\begin{tabular}{cccc}
\hline $\begin{array}{c}\text { Bioclimatic and } \\
\text { Environmental Variables }\end{array}$ & Acronym & Contribution \% & $\begin{array}{c}\text { Permutation } \\
\text { Importance }\end{array}$ \\
\hline Isothermality & bio3 & 9.4 & 0.7 \\
Temperature Seasonality (sd $\times 100)$ & bio4 & 0.0 & 0.0 \\
Max Temperature of Warmest Month & bio5 & 0.0 & 0.0 \\
Temperature Annual Range (bio5-bio6) & bio7 & 5.8 & 4.1 \\
Mean Temperature of Driest Quarter & bio9 & 34 & 47.2 \\
Mean Temperature of Warmest Quarter & bio10 & 6.8 & 24 \\
Annual Precipitation & bio12 & 0.0 & 0.0 \\
Precipitation of Wettest Month & bio13 & 0.5 & 0.0 \\
Precipitation of Driest Month & bio14 & 24.6 & 4.0 \\
Precipitation Seasonality & bio15 & 0.8 & 7.9 \\
Precipitation Wettest Quarter & bio16 & 0.0 & 0.0 \\
Precipitation Warmest Quarter & bio18 & 0.5 & 0.1 \\
Altitude & Alt & 2.3 & 2.8 \\
Soil Type & Soil & 9.4 & 7.2 \\
Soil Moisture & Humsoil & 0.8 & 0.4 \\
Land use and Vegetation & Land Use & 0.0 & 0.0 \\
Forest Cover & Treecover & 5.1 & 1.7 \\
\hline
\end{tabular}

The program MaxEnt was used to determine the potential distribution of V. planifolia. MaxEnt is based on a statistical approximation known as maximum entropy that allows predictions to be made using incomplete information from the presence data [34]. As a result, we obtained the environmental variables necessary for the potential establishment of $V$. planifolia (Table 1). The model was run with 500 iterations and the extrapolation and clamping options were deactivated, selecting $30 \%$ of the points for the validation of the model. The Jackknife test [43] was applied in order to indicate the variables that best explained the presence of the species. After several tests in MaxEnt, considering the most important variables, the model that best fit the potential distribution was selected.

Model validation was carried out using the area under the curve (AUC) of the Receiver Operating Characteristic (ROC) analysis. The analysis parameters indicate the sensitivity of the variables predicting the presence and the specificity of the absence of the species. AUC values are between 0.5 and 1.0, with values closer to 1.0 indicating a better discrimination, representing a greater probability of occurrence [44]. The 10th percentile threshold was used because good results have been shown using thresholds from 1 to 10th percentile [45]. The Tool for Partial-ROC program [46] was also used to validate the model, applying the partial ROC curves test [47] with values $>1$, with $50 \%$ of the independent evaluation points in bootstrap, 1000 replications, and an error of omission of less than $5 \%$ (1-omission threshold $>0.95$ ).

\subsection{Climate Change Projections}

Projections for the future distribution of $V$. planifolia were made considering that climate change and increased atmospheric carbon scenarios will modify the distribution of the species and may even cause its extinction [48]. The following global climate model data were used from WorldClim v.1.4 [30,49]: HadGEM2-ES (Hadley Centre Global Environment Model v.2 Earth System), GFDL-CM3 (Geophysical Fluid Dynamics Laboratory Climate Model, v.3), MPI-ESM-LR (Max Planck Institute Earth System Model, Low Resolution), CCSM3 (Community Climate System Model, v.3), and CGCM3 (Coupled Global Climate Model v.3) at $30 \mathrm{~s}$ spatial resolution $\left(\sim 1 \mathrm{~km}^{2}\right)$, with two-path scenarios of representative concentrations (RCP) of accumulation of greenhouse gases: (i) intermediate scenario-temperature rise of 1.1 to $2.6^{\circ} \mathrm{C}$ (RCP 4.5), and (ii) scenario-from 2.6 to $4.8^{\circ} \mathrm{C}$ (RCP 8.5; [50]), for the corresponding periods between 2041-2060 (2050) and 2061-2080 (2070). For this modeling, only the climate layers of the most important variables were 
used (isothermality, annual temperature range, mean temperature of the driest quarter, mean temperature of the warmest quarter, precipitation of the driest month, seasonal precipitation, precipitation of the warmest quarter, altitude, soil type, soil moisture, and forest cover), because future projections exist for them; soil and altitude were assumed to remain steady over time because their processes of formation and change occur on broad time scales. To obtain the projected areas suitable, all the models were added through the binary method, contrasting it with the current potential distribution model and considering the 10th percentile training threshold indicated for each model. In addition, the extent of areas with 60 and $80 \%$ suitability in each modeled period were estimated.

\section{Results}

\subsection{Potential Distribution}

The AUC and partial ROC values were 0.96 and 1.40, respectively, indicating that the real and potential distribution are similar; therefore, the model presents an adequate confidence level, since the probability of error is less than $1 \%$. Twelve of the environmental variables were of greatest importance, of which seven contributed 95\% to the model: mean temperature of the driest quarter $(34 \%)$, precipitation of the driest month $(24.6 \%)$, soil type $(9.4 \%)$, isothermality $(9.4 \%)$, mean temperature of the warmest quarter $(6.8 \%)$, annual temperature range $(5.8 \%)$, and forest cover $(5.1 \%)$ (Table 1$)$.

The model indicates that the area with the greatest potential for the establishment of V. planifolia is the northern Veracruz state, adjacent to the state of Puebla (humid forest ecoregion of Veracruz), specifically the Totonacapan region, in addition to northeast Oaxaca (humid forest ecoregion Petén-Veracruz) (Figure 2). The preferable altitude is between 5 and $850 \mathrm{~m}$ asl, with a mean altitude of $160 \mathrm{~m}$. The preferable mean temperature is $22{ }^{\circ} \mathrm{C}$ in the months of February, March, and April. In the rest of southeast Mexico (southern Oaxaca, Chiapas, Tabasco, and Yucatan Peninsula), there were no favorable sites for the development of $V$. planifolia (Figure 2).

\subsection{Species Projections with Climate Change Scenarios}

The projections for the average years 2050 and 2070 of the species $V$. planifolia show a progressive reduction in potential area (Table 2, Figure 3). In both projections, the reductions range between -1.6 and $-17.3 \%$ for the years 2050 and 2070, with the greatest reductions recorded in the model with the highest temperature increase (RPC8.5) and for 2070. It is important to note that despite the reduction of potential area in all of the study ecoregions, the Totonacapan region (northern Veracruz state and bordering the state of Puebla) maintains the largest extent of areas suitable for vanilla, although declines between 9 and 20\% are projected for the years 2050 and 2070, respectively (Figure 3). Drastic decreases in potential area are projected for northeast Oaxaca (more than 50\% of the potential area in any of the projections) and the Huasteca Potosina, located on the border between San Luis Potosí and Hidalgo; the other study ecoregions are projected to continue to be unsuitable because the temperature of driest quarter increases and the precipitation of the driest month decreases (Figure 1). The most important variables explaining the reduction in suitable areas were the average temperature of the driest quarter, the precipitation of the driest month, and the soil type (Table 2). 


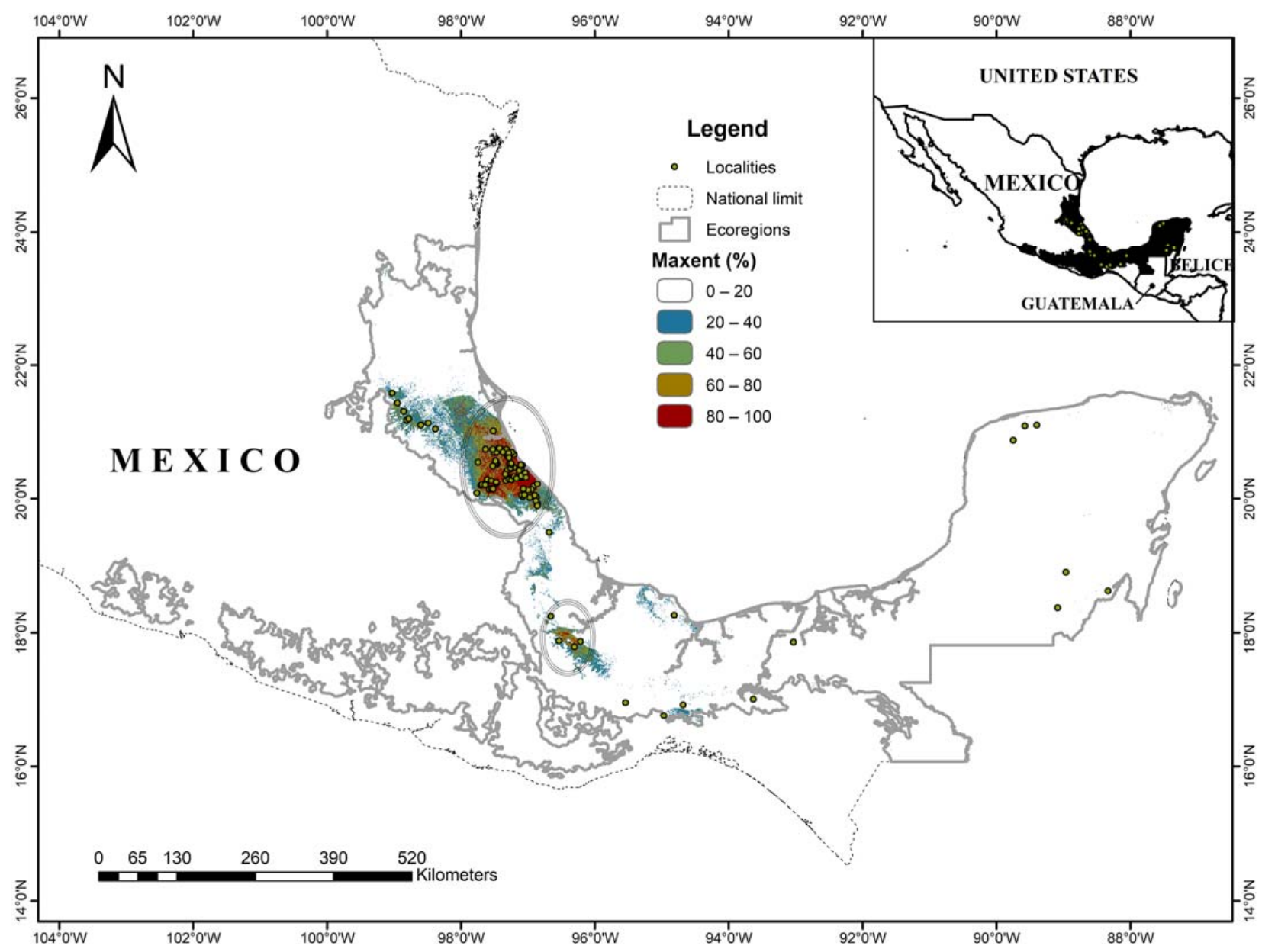

Figure 2. Real and potential distribution of Vanilla planifolia according to the maximum entropy model (Maxent). The red color represents the highest probability of registering the species. The ovals indicate the areas with the highest suitability.

Table 2. Current distribution and future projections in Mexico for Vanilla planifolia with two climatic scenarios, generated in the Maxent model. The percentage reduction of the potential area is indicated in parentheses. $\mathrm{RCP} 4.5=$ intermediate scenario; temperature rise of $1.1^{\circ} \mathrm{C}$ to $2.6^{\circ} \mathrm{C} ; \mathrm{RCP} 8.5=$ high emissions scenario; temperature rise of $2.6{ }^{\circ} \mathrm{C}$ to $4.8^{\circ} \mathrm{C}$.

\begin{tabular}{|c|c|c|c|c|c|}
\hline Variables & Current area & $\begin{array}{c}\text { RCP4.5 } \\
2050\end{array}$ & $\begin{array}{c}\text { RCP4.5 } \\
2070\end{array}$ & $\begin{array}{c}\text { RCP8.5 } \\
2050\end{array}$ & $\begin{array}{c}\text { RCP8.5 } \\
2070\end{array}$ \\
\hline AUC & 0.96 & 0.95 & 0.95 & 0.96 & 0.95 \\
\hline $\begin{array}{l}\text { Potential area } \\
\left(>60 \%, \mathrm{~km}^{2}\right)\end{array}$ & 9308.30 & $\begin{array}{l}8594.71 \\
(-7.7 \%)\end{array}$ & $\begin{array}{c}8380.63 \\
(-10.0 \%)\end{array}$ & $\begin{array}{l}8411.24 \\
(-9.6 \%)\end{array}$ & $\begin{array}{c}7698.31 \\
(-17.3 \%)\end{array}$ \\
\hline $\begin{array}{l}\text { Potential area } \\
\left(>80 \%, \mathrm{~km}^{2}\right)\end{array}$ & 5059.82 & $\begin{array}{l}4979.78 \\
(-1.6 \%)\end{array}$ & $\begin{array}{l}4834.73 \\
(-4.4 \%)\end{array}$ & $\begin{array}{c}4544.16 \\
(-10.2 \%)\end{array}$ & $\begin{array}{c}4497.32 \\
(-11.4 \%)\end{array}$ \\
\hline $\begin{array}{l}\text { Important } \\
\text { variables } \\
\text { (contribu- } \\
\text { tion }>10 \% \text { ) }\end{array}$ & $\begin{array}{l}\text { Mean temperature } \\
\text { of driest quarter, } \\
\text { precipitation of } \\
\text { driest month }\end{array}$ & $\begin{array}{l}\text { Mean temperature } \\
\text { of driest quarter, } \\
\text { precipitation of } \\
\text { driest month, soil } \\
\text { type, isothermality }\end{array}$ & $\begin{array}{l}\text { Mean temperature } \\
\text { of driest quarter, } \\
\text { precipitation of } \\
\text { driest month, soil } \\
\text { type, isothermality, } \\
\text { Max temperature } \\
\text { of warmest month }\end{array}$ & $\begin{array}{l}\text { Mean temperature } \\
\text { of driest quarter, } \\
\text { precipitation of } \\
\text { driest month, soil } \\
\text { type, isotermality }\end{array}$ & $\begin{array}{l}\text { Mean temperature } \\
\text { of driest quarter, } \\
\text { precipitation of } \\
\text { driest month, } \\
\text { soil type }\end{array}$ \\
\hline
\end{tabular}



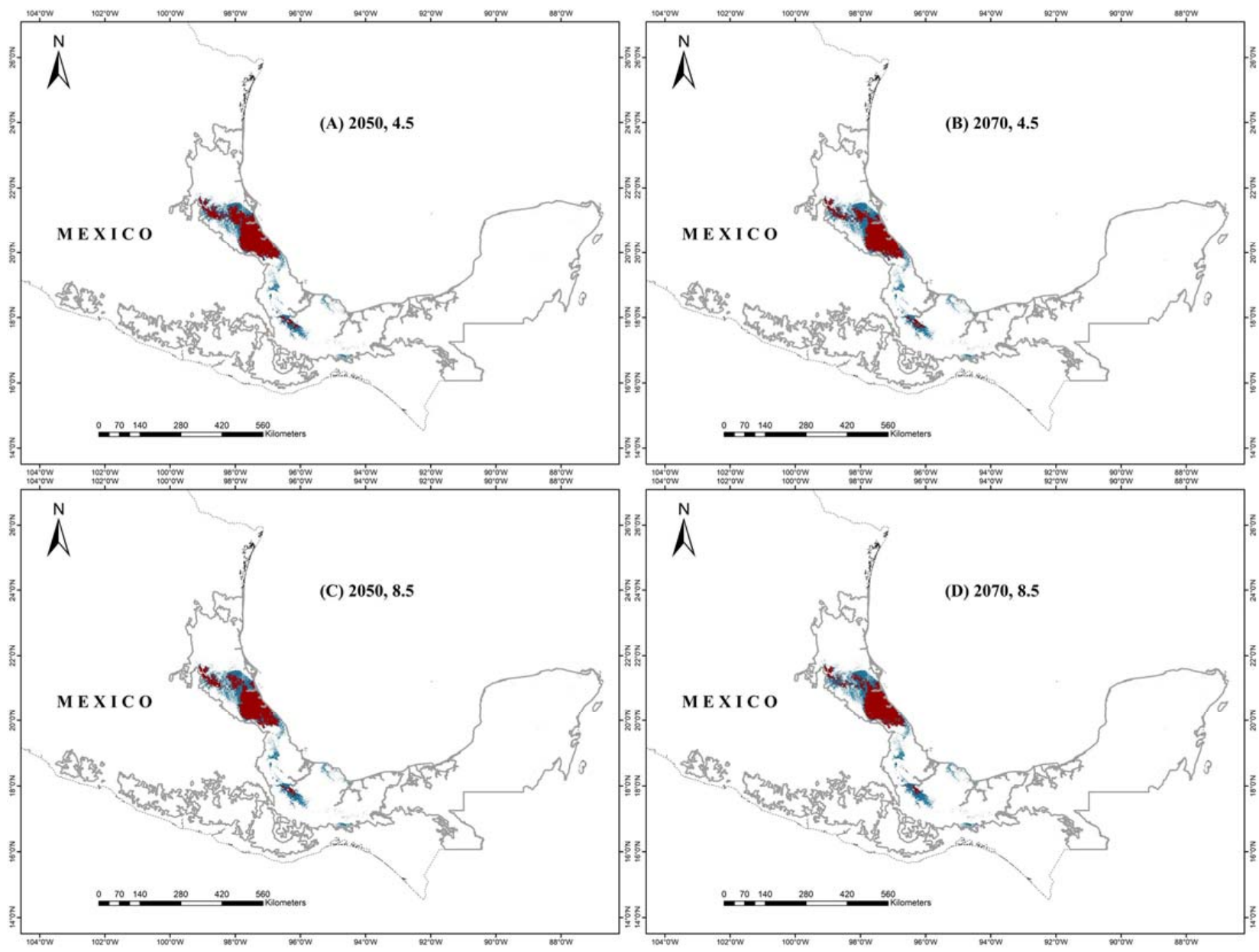

Figure 3. Future projections of the distribution of Vanilla planifolia under different climate scenarios (RCP4.5 and RCP8.5) for the years 2050 and 2070. The white color represents the unsuitable area for the species, the blue the suitable area lost during that period, and red the suitable area to be maintained during climate change. (A) 2050 (RCP 4.5), (B) 2070 (RCP 4.5), (C) 2050 (RCP 8.5), and (D) 2070 (RCP 8.5).

\section{Discussion}

Various studies have documented that climate change has negative effects on the production and distribution of different crops [4,6,51,52]. In Mexico, vanilla production has faced problems associated with prolonged dry spells and high temperatures [18]. In this study, we corroborate that the potential distribution of $V$. planifolia is mainly associated with the ecoregions and tropical humid ecosystems of southeastern Mexico. However, the future distribution projected under both climate models shows a consistent reduction in the distribution of suitable areas. Therefore, it is necessary to develop strategies that favor the sustainable management and conservation of this species.

\subsection{Potential Distribution}

The potential distribution results show that the most suitable areas for the development and cultivation of $V$. planifolia have tropical climatic conditions associated with humid lowland forests, mainly in the northern region of the state of Veracruz, in the southern and southeastern states of Mexico, similar to that reported by other authors $[9,13,53]$. These areas conserve favorable climatic conditions for the development and cultivation of the species, with average annual rainfall between 1500 and $2500 \mathrm{~mm}$, average temperatures of 21 and $27^{\circ} \mathrm{C}$ and maximum temperatures of $33^{\circ} \mathrm{C}[13,14]$. In our study, the altitudinal distribution interval of $V$. planifolia was restricted to an interval of 5 to $850 \mathrm{~m}$ asl, which differs from that reported by Flores-Jiménez et al. [13], who determined a wider interval (from 0 to 
$1650 \mathrm{~m}$ asl), which influenced the temperature values where the species can be found (16.7 to $27.8^{\circ} \mathrm{C}$ ). The altitudinal distribution of vanilla is a relevant factor for the preservation of its aromatic properties [13]. In our study, the average temperature of the driest quarter and precipitation of the driest month were relevant climatic variables for determining the suitability of distribution areas, similar to those reported by Flores-Jiménez et al. [13]. In particular, the average temperature of $22{ }^{\circ} \mathrm{C}$ in the months of February, March, and April is fundamental in the species distribution [54]. The average temperature of the driest months can be very important to vanilla's reproductive process because it coincides with the flowering season of vanilla in Mexico, which occurs during March and April [9]. It has been reported that at average temperatures between 25 and $30^{\circ} \mathrm{C}$, the highest pollen germination percentages and a greater elongation of the pollen tube are achieved, which can affect the binding of vanilla fruits [55]. Another of the determining variables is soil type, which is relevant for the development and growth of $V$. planifolia $[56,57]$ and other aromatic species [22]. V. planifolia establishes on porous soils with low apparent density, as long as they have good drainage [58].

\subsection{Distribution Patterns of Vanilla planifolia as a Function of Climate Change Models}

In recent decades, changing climate patterns have determined the displacement of agricultural species distribution ranges, changes in their phenological patterns, and negative effects on production, leading to the declaration of a food alert [50]. The climate projections developed in this study show that the distribution area of $V$. planifolia will be considerably reduced in the future, associated with changes in the mean temperature of the driest quarter, the precipitation of the driest month, and soil type. In both models, suitable conditions disappear in several ecoregions where $V$. planifolia is potentially distributed and only three important regions remain: the Huasteca Potosina, the Totonacapan region (northern Veracruz state and bordering the state of Puebla) and the northeast region of Oaxaca state. These regions are very relevant in terms of the production and conservation of vanilla. The Huasteca Potosina and Totonacapan regions are the most important vanilla production areas in Mexico [53] and northeast Oaxaca supports wild vanilla populations [9,59] and the greatest diversity of vanilla species in the country [11].

The loss of suitable conditions for $V$. planifolia in various regions may have important repercussions for the planning strategy to increase vanilla production in Mexico (2017-2030 [60]), which prioritizes promoting production in the eight states where production already exists (Nuevo León, Tamaulipas, San Luis Potosí, Querétaro, Puebla, Veracruz, Oaxaca, Chiapas, and Tabasco [13]). In our results for the years 2050 and 2070, only four states (San Luis Potosí, Puebla, Veracruz, and Oaxaca) will have favorable conditions and the altitude range below $850 \mathrm{~m}$ asl. The expansion of cultivation areas is a strategy that has been implemented in other crops [4]. In the case of vanilla, these actions are already being carried out through various initiatives seeking to establish crops in the states of Yucatán, Quintana Roo, Chiapas, and the central region of Veracruz, in different ecosystems and altitudinal ranges $[23,24]$. However, the viability of these crops remains uncertain due to lack of technical training for management of the species, scarce investment resources for crop establishment, and an uncertain market scheme, among other problems [58,61]. In addition, expansion of the vanilla crop beyond its natural range can modify its aromatic properties, which have been shown to be related to the climatic and environmental conditions of the sites where it is developed [13,62]. Therefore, the expansion of vanilla cultivation areas must be critically reviewed under different climate change scenarios and the socio-cultural and economic contexts that determine viability of these proposals $[4,13]$.

The reduction in the potential distribution of the vanilla crop in the Totonacapan region will have strong repercussions for the production and future management of the species. This region is the most important productive region in Mexico, and that for the years 2050 and 2070 suitable conditions for vanilla cultivation will remain in very restricted areas. The negative effects of climate change on the production of vanilla are currently latent; diseases and premature fruit drop have increased, which reduce production [18]. Producers have 
developed different strategies to address this problem ranging from production modernization (shade houses with irrigation systems), the cultivation of vanilla in citrus production areas [53], to revitalizing traditional cultivation systems [25,61]. Technified production has been used by a small number of producers having favorable economic resources and technical support; however, this strategy is not widely applicable to the majority of small producers, who have very small plots and unfavorable economic conditions. In addition, in many cases the adoption of these strategies can bring unwanted consequences such as a decrease in productive diversification, high demands for water consumption, contamination of water sources due to the use of agrochemicals, and the generation of new pests, which altogether may result in low resilience to climate variability [4].

Other strategies have favored productive diversification models through the use of agroforestry systems, as has been used in other crops (e.g., coffee plantations) in various regions of Latin America [4,63]. Traditional vanilla production systems are being revitalized in which vanilla is grown in secondary forests where shade level and soil humus are managed. The trees used as stakes are multi-purpose native species [25] that generate microclimatic and edaphic conditions favorable for the development and production of vanilla. The importance of these traditional systems should be assessed as a strategy to face the periods of drought and high temperatures that have recently become more frequent in the main vanilla production regions. In general, the use of shade trees can protect vanilla plants from extreme climatic changes and improve soil fertility, giving greater resilience to plantations, as has been described for shade coffee plantations [64]. However, it is important to analyze the effects that shade trees may have in relation to the management of pests, diseases, and biological control agents, since contradictory impacts have been recorded in other agroecosystems $[4,64]$. Another relevant aspect of traditional vanilla systems is that they are based on traditional ecological knowledge, with central elements including heterogeneous land use, productive diversification, and use of multipurpose species for auto-consumption [25]. It is also important to develop a climate alert system that helps farmers to counteract the impact of extreme events. These attributes may favor the design of strategies for sustainable management and production of the species.

Given the projected reduction of distribution areas due to climate change in the most important vanilla production regions, another important problem to address is the crop's reduced genetic diversity $[12,13,20,21,59]$. The principal strategies that have been applied in other crops are adoption of varieties and development of hybrids resistant to pests and drought, ex situ conservation through germplasm banks, etc. [4]. In the case of vanilla, proposals have been made to use wild populations to genetically improve the cultivation areas, as well as to develop new hybrids resistant to pests and droughts [24]. Some species in the genus Vanilla (e.g., V. pompona and V. odorata) are confirmed to have bioclimatic profiles allowing them to develop in high temperatures and resist drought; these could be used to develop new hybrids $[13,24]$. The developments in situ and ex situ conservation strategies for vanilla are in this sense very important to increase the response capacities of the species to environmental changes [65].

Another region with continued favorable conditions for vanilla distribution is northeast Oaxaca, although it faces a very significant reduction in potential area of more than $50 \%$. This region supports wild vanilla populations with the greatest genetic diversity and the highest percentages of aromatic components reported [66], for which it may be considered a conservation priority for this genus [12,59]. Currently, V. planifolia is in danger of extinction under natural conditions due to habitat destruction, the overcollection of natural populations for the establishment of new crops, and mismanagement of the species $[23,65]$. It is therefore urgent to develop and design in situ vanilla conservation strategies. However, the viability of these proposals is seriously questioned because the areas where natural vanilla populations are distributed are strongly altered and anthropogenic pressures threaten their persistence [55,65]. Despite this, in situ conservation measures should be insisted upon in forests with favorable conditions, since it is the most appropriate way to conserve the genetic variability of the genus Vanilla $[12,59,65]$. In Mex- 
ico, particularly in northern Oaxaca, large areas of tropical forest still persist in a good state of conservation [67]. There are successful community initiatives in this region for the conservation of tropical humid forests, which maintain high biodiversity $[67,68]$. Strategies to protect populations of the region's known vanilla species and reintroduce genetic diversity could be inserted within these conservation initiatives [23]. Another relevant approach to conserving the genetic variation of vanilla are ex situ strategies through the establishment of germplasm banks, considered the most viable measure to preserve genotypes [12,23,65]. Although this strategy has been developed in different countries since the middle of the last century, its success has been questioned because many collections were abandoned [23]. In Mexico, the Universidad Veracruzana maintains the Vanilla collection, with specimens of 71 accessions from different origins in the country [24].

\section{Conclusions}

In our study we confirm that the current potential distribution of $V$. planifolia is associated with tropical humid ecosystems of southeastern Mexico. The bioclimatic model projections generated for the years 2050 and 2070 universally forecast the reduction of both potential cultivation areas and natural distribution areas. In most of the ecoregions of southeast Mexico, suitable conditions for the development of the species disappear, and only reduced areas remain in the Totonacapan region and northeast Oaxaca. Vanilla production is currently rebounding in different regions of Mexico, and in the Totonacapan region it is being strongly promoted by the Programa Nacional de Sembrando Vida [69]. However, as we have discussed, this crop will face important challenges in light of the evaluated climate change scenarios. Therefore, sustainable management strategies for vanilla must be developed, adapted to climate change scenarios, and with participation from all involved actors (government, businesses, producers, researchers, NGOs, etc.). These management strategies could follow the schemes of climate-smart agriculture, where productivity and income of producers are sustainably increased, adaptation and resilience to climate change is developed, and greenhouse gas emissions are reduced or eliminated [4,70]. In addition, it is necessary to develop an integrated, national strategy for the conservation of vanilla's genetic diversity that will address the challenges of climate change.

Author Contributions: The conception and design of the work, methodology, formal analysis, writing, S.A.-M. and N.V.-R.; Review, project administration, funding acquisition, R.M.-G. and A.P.-S. All authors have read and agreed to the published version of the manuscript.

Funding: This research was financed by FORDECYT-CONACYT through the Project (297484) "Strategies for climate change adaptation and mitigation necessary for the rescue of vanilla cultivation in Mexico".

Institutional Review Board Statement: Not applicable.

Informed Consent Statement: Not applicable.

Data Availability Statement: Not applicable.

Acknowledgments: We thank A. R. Cortes, technical manager of the Sembrando Vida Papantla program, the producers of the municipalities of Cazones, Papantla de Olarte, and Gutiérrez Zamora in Veracruz, and Cuetzalan in Puebla, the company Vanilla and Spice, S. A. de C.V for the information provided on the distribution of vanilla cultivation sites, and B. Ruiz Guerra for comments on a previous draft.

Conflicts of Interest: The authors declare no conflict of interest.

\section{References}

1. Altieri, M.A.; Nicholls, C.I. Agroecología y resiliencia al cambio climático: Principios y consideraciones metodológicas. Agroecología 2013, 8, 7-20.

2. Zimmerer, K.S.; Haan, S. Agrobiodiversity and a sustainable food future. Nat. Plants 2017, 3, 1-3. [CrossRef]

3. Battisti, D.S.; Naylor, R.L. Historical warnings of future food insecurity with unprecedented seasonal heat. Science 2009, 323, 240-244. [CrossRef] 
4. Taboada, M.A.; Busto, M.; Costantini, A.O.; Maggio, A.; Perin, A.; Pimentel, M.S.; Alfaro, M.A.; Pons-Ganddini, D.; Monterroso-Rivas, A.I.; Loboguerrero, A.M. Sector Agropecuario. In Adaptación Frente a los Riesgos del Cambio Climático en los Países Iberoamericanos_Informe RIOCCADAPT, 1st ed.; Moreno, J.M., Laguna-Defior, C., Barros, V., Calvo Buendía, E., Marengo, J.A., Oswald Spring, U., Eds.; McGraw-Hill: Madrid, España, 2020; pp. 237-290.

5. $\quad$ Porter, J.R.; Xie, L.; Challinor, A.J.; Cochrane, K.; Howden, S.M.; Iqbal, M.M.; Lobell, D.B.; Travasso, M.I. Food security and food production systems. In Climate Change 2014: Impacts, Adaptation, and Vulnerability. Part A: Global and Sectoral Aspects. Contribution of Working Group II to the Fifth Assessment Report of the Intergovernmental Panel on Climate Change, 1st ed.; Field, C.B., Barros, V.R., Dokken, D.J., Mach, K.J., Mastrandrea, M.D., Bilir, T.E., Chatterjee, M., Ebi, K.L., Estrada, Y.O., Genova, R.C., et al., Eds.; Cambridge University Press: Cambridge, UK; New York, NY, USA, 2014; pp. 485-533.

6. Van Oort, P.A.; Zwart, S.J. Impacts of climate change on rice production in Africa and causes of simulated yield changes. Glob. Chang. Biol. 2018, 24, 1029-1045. [CrossRef]

7. Wang, B.; Liu, D.L.; O’Leary, G.J.; Asseng, S.; Macadam, I.; Lines-Kelly, R.; Yang, X.; Clark, A.; Crean, J.; Sides, T.; et al. Australian wheat production expected to decrease by the late 21st century. Glob. Chang. Biol. 2017, 24, 2403-2415. [CrossRef] [PubMed]

8. Vincent, H.; Amri, A.; Castañeda-Álvarez, N.P.; Dempewolf, H.; Dulloo, E.; Guarino, L.; Hole, D.; Mba, C.; Toledo, A.; Maxted, N. Modeling of crop wild relative species identifies areas globally for in situ conservation. Commun. Biol. 2019, 2, 1-8. [CrossRef] [PubMed]

9. Soto-Arenas, M.A.; Dressler, R.L. A revision of the Mexican and Central American species of Vanilla Plumier ex Miller with a characterization of their ITS region of the nuclear ribosomal DNA. Lankesteriana 2010, 9, 285-354. [CrossRef]

10. Pérez-Silva, A.; Günata, Z.; Lepoutre, J.P.; Odoux, E. New insight on the genesis and fate of odor- active compounds in vanilla beans (Vanilla planifolia G. Jackson) during traditional curing. Food Res. Int. 2011, 44, 2930-2937. [CrossRef]

11. Lubinsky, P.; Bory, S.; Hernández-Hernández, J.; Kim, S.-C.; Gómez-Pompa, A. Origins and Dispersal of Cultivated Vanilla (Vanilla planifolia Jacks. [Orchidaceae]). Econ. Bot. 2008, 62, 127-138. [CrossRef]

12. Soto-Arenas, M.A. Filogeografía y recursos genéticos de las vainillas de México; Instituto Chinoin AC, Comisión nacional para el conocimiento y uso de la biodiversidad: Mexico City, México, 1999.

13. Flores-Jiménez, A.; Reyes López, D.; Jiménez García, D.; Romero Arenas, O.; Rivera Tapia, J.A.; Huerta Lara, M.; Pérez Silva, A. Diversidad de Vanilla spp. (Orchidaceae) y sus perfiles bioclimáticos en México. Rev. Biol. Trop. 2017, 65, 975-987. [CrossRef]

14. Hernández-Ruíz, J.; Herrera-Cabrera, B.E.; Delgado-Alvarado, A.; Salazar-Rojas, V.M.; Bustamante-González, Á.; CamposContreras, J.E.; Ramírez-Juárez, J. Distribución potencial y características geográficas de poblaciones silvestres de Vanilla planifolia (Orchidaceae) en Oaxaca, México. Rev. Biol. Trop. 2016, 64, 235-246. [CrossRef]

15. Convención Sobre el Comercio Internacional de Especies Amenazadas de Fauna y Flora (CITES). Apéndices I, II y III. Available online: https:/ / cites.org/sites/default/files/esp/app/2015/S-Appendices-2015-02-15.pdf (accessed on 30 December 2021).

16. Vega, M.; Hernández, M.; Herrera-Cabrera, B.E.; Wegier, A. Vanilla Planifolia (Amended Version of 2017 Assessment). The IUCN Red List of Threatened Species 2020: E.T103090930A172970359. Available online: https://doi.org/10.2305/IUCN.UK.2020-2 .RLTS.T103090930A172970359.en (accessed on 7 February 2022).

17. Food and Agriculture Organization of the United Nations (FAOSTAT). Food and Agriculture Data. Available online: http: / / faostat.fao.org/ (accessed on 30 September 2021).

18. Villarreal-Manzo, L.A.; Herrera-Cabrera, B.E. Requerimiento hídrico en el sistema de producción vainilla (Vanilla planifolia Jacks ex Andrews)-NARANJO (Citrus sinensis L.) en la región del totonacapan, Veracruz, México. Agroproductividad 2018, 11, $29-36$.

19. Pérez-Silva, A.; Nicolás-García, M.; Petit, T.; Dijoux, J.B.; Vivar-Vera, M.A.; Besse, P.; Grisoni, M. Quantification of the aromatic potential of ripe fruit of Vanilla planifolia (Orchidaceae) and several of its closely and distantly related species and hybrids. Eur. Food Res. Technol. 2021, 247, 1489-1499. [CrossRef]

20. Salazar-Rojas, V.M.; Herrera-Cabrera, B.E.; Delgado-Alvarado, A.; Soto-Hernández, M.; Castillo-González, F.; Cobos-Peralta, M. Chemotypical variation in Vanilla planifolia Jack. (Orchidaceae) from the Puebla-Veracruz Totonacapan region. Genet. Resour. Crop Evol. 2012, 59, 875-887. [CrossRef]

21. Villanueva-Viramontes, S.; Hernández-Apolinar, M.; Fernández-Concha, G.C.; Dorantes-Euán, A.; Dzib, G.R.; Castillo, J.M. Wild Vanilla planifolia and its relatives in the Mexican Yucatan Peninsula: Systematic analyses with ISSR and ITS. Bot. Sci. 2017, 95, 169-187. [CrossRef]

22. Watteyn, C.; Fremout, T.; Karremans, A.P.; Huarcaya, R.P.; Bolaños, J.B.A.; Reubens, B.; Muys, B. Vanilla distribution modeling for conservation and sustainable cultivation in a joint land sparing/sharing concept. Ecosphere 2020, 11, 1-18. [CrossRef]

23. Azofeifa-Bolaños, J.B.; Paniagua-Vásquez, A.; García-García, J.A. Importancia y desafíos de la conservación de Vanilla spp.(Orquidaceae) en Costa Rica. Agron. Mesoam. 2014, 25, 189-202. [CrossRef]

24. Menchaca, R.; Lozano Rodríguez, M. Vainilla, la orquídea que aromatiza al mundo. In Las Orquídeas de Veracruz, 1st ed.; Viccon Esquivel, J., Castañeda Zarate, M., Castro Cortes, R., Cetzal Ix, W., Eds.; Universidad Veracruzana: Xalapa, México; Veracruz México, 2021; pp. 123-1333.

25. Velázquez-Rosas, N.; Silva-Rivera, E.; Ruiz-Guerra, B.; Armenta-Montero, S.; González, J.T. Traditional Ecological Knowledge as a tool for biocultural landscape restoration in northern Veracruz, Mexico. Ecol. Soc. 2018, 23, 6. [CrossRef]

26. Wisz, M.S.; Hijmans, R.J.; Li, J.; Peterson, A.T.; Graham, C.H.; Guisan, A.; NCEAS Predicting Species Distributions Working Group. Effects of sample size on the performance of species distribution models. Divers. Distrib. 2008, 14, 763-773. [CrossRef] 
27. Austin, M.P.; Van Niel, K.P. Improving species distribution models for climate change studies: Variable selection and scale. J. Biogeogr. 2011, 28, 1-8. [CrossRef]

28. Bede-Fazekas, Á.; Somodi, I. The way bioclimatic variables are calculated has impact on potential distribution models. Methods Ecol. Evol. 2020, 11, 1559-1570. [CrossRef]

29. Feilhauer, H.; He, K.S.; Rocchini, D. Modeling species distribution using niche-based proxies derived from composite bioclimatic variables and MODIS NDVI. Remote Sens. 2012, 4, 2057-2075. [CrossRef]

30. Fick, S.E.; Hijmans, R.J. WorldClim 2: New 1-km spatial resolution climate surfaces for global land areas. Int. J. Climatol. 2017, 37, 4302-4315. [CrossRef]

31. Karger, D.N.; Conrad, O.; Böhner, J.; Kawohl, T.; Kreft, H.; Soria-Auza, R.W.; Zimmermann, N.E.; Linder, P.; Kessler, M. Climatologies at high resolution for the Earth land surface areas. Sci. Data 2017, 4, 1-20. [CrossRef]

32. Booth, T.H. Why understanding the pioneering and continuing contributions of BIOCLIM to species distribution modelling is important. Austral Ecol. 2018, 43, 852-860. [CrossRef]

33. Chun, J.H.; Lee, C.B.; Yoo, S.M. Shifts of geographic distribution of Pinus koraiensis based on climate change scenarios and GARP model. Korean J. Agric. For. Meteorol. 2015, 17, 348-357. [CrossRef]

34. Phillips, S.J.; Anderson, R.P.; Schapire, R.E. Maximum entropy modeling of species geographic distributions. Ecol. Modell. 2006, 190, 231-259. [CrossRef]

35. Instituto Nacional de Estadística y Geografía (INEGI). Catálogo Único de Claves de Áreas Geoestadísticas Estatales, Municipales y Localidades. 2021. Available online: https:/ / www.inegi.org.mx/app/ageeml/ (accessed on 20 February 2021).

36. Soberón, J.; Peterson, A.T. Interpretation of models of fundamental ecological niches and species' distributional areas. Biodiv. Inf. 2005, 2, 1-10. [CrossRef]

37. Olson, D.M.; Dinerstein, E.; Wikramanayake, E.D.; Burgess, N.D.; Powell, G.V.; Underwood, E.C.; D'amico, J.A.; Itoua, I.; Strand, H.E.; Morrison, J.C.; et al. Terrestrial ecoregions of the world: A new map of life on Earth. BioScience 2001, 51, 933-938. [CrossRef]

38. Hansen, M.C.; Potapov, P.V.; Moore, R.; Hancher, M.; Turubanova, S.A.; Tyukavina, A.; Thau, D.; Stehman, S.V.; Goetz, S.J.; Loveland, T.R.; et al. High-Resolution Global Maps of 21st-Century Forest Cover Change. Science 2013, 342, 850-853. [CrossRef]

39. Instituto Nacional de Estadística y Geografía (INEGI). Carta de Uso del Suelo y Vegetación. Serie V, 1:250 000; INEGI: Aguascalientes, México, 2016.

40. Instituto Nacional de Estadística y Geografía (INEGI). Conjunto de Datos Vectoriales Edafológico, Serie II, 1:250000; INEGI: Aguascalientes, México, 2014.

41. Comisión Nacional de Biodiversidad (CONABIO). Regímenes de Humedad del suelo, 1:4000000; CONABIO: Mexico City, México, 2002.

42. Dormann, C.F.; Elith, J.; Bacher, S.; Buchmann, C.; Carl, G.; Carré, G.; García-Marquéz, J.R.; Gruber, B.; Lafourcade, B.; Leitäo, P.J.; et al. Collinearity: A review of methods to deal with it and a simulation study evaluating their performance. Ecography 2013, 36, 27-46. [CrossRef]

43. Pearson, R.G.; Raxworthy, C.J.; Nakamura, M.; Peterson, T. Predicting species distributions from small numbers of occurrence records: A test case using cryptic geckos in Madagascar. J. Biogeogr. 2007, 34, 102-117. [CrossRef]

44. Baldwin, R.A. Use of maximum entropy modeling in wildlife research. Entropy 2009, 11, 854-866. [CrossRef]

45. Fernández, I.C.; Morales, N.S. One-class land-cover classification using MaxEnt: The effect of modelling parameterization on classification accuracy. Peer] 2019, 7, e7016. [CrossRef]

46. Peterson, A.T.; Papeş, M.; Soberón, J. Rethinking receiver operating characteristic analysis applications in ecological niche modeling. Ecol. Modell. 2008, 213, 63-72. [CrossRef]

47. Narayani, B. Tool for Partial-ROC; Biodiversity Institute: Kansas, KS, USA, 2008.

48. Thuiller, W.; Lavorel, S.; Araújo, M.B.; Sykes, M.T.; Prentice, I.C. Climate change threats to plant diversity in Europe. Proc. Natl. Acad. Sci. USA 2005, 102, 8245-8250. [CrossRef]

49. Randall, D.A.; Wood, R.A.; Bony, S.; Colman, R.; Fichefet, T.; Fyfe, J.; Kattsov, V.; Pitman, A.; Shukla, J.; Srinivasan, J.; et al. Climate models and their evaluation. In Climate Change 2007: The Physical Science Basis. Contribution of Working Group I to the Fourth Assessment Report of the Intergovernmental Panel on Climate Change, 1st ed.; Solomon, S., Qin, D., Manning, M., Chen, Z., Marquis, M., Averyt, K.B., Tignor, M., Miller, H.L., Eds.; Cambridge University Press: Cambridge, UK; New York, NY, USA, 2007; pp. $589-662$.

50. Stocker, T.F.; Qin, D.; Plattner, G.-K.; Tignor, M.; Allen, S.K.; Boschung, J.; Nauels, A.; Xia, Y.; Bex, V.; Midgley, P.M. (Eds.) Climate Change 2013: The Physical Science Basis. Contribution of Working Group I to the Fifth Assessment Report of the Intergovernmental Panel on Climate Change; Cambridge University Press: Cambridge, UK; New York, NY, USA, 2013; 1535p.

51. Zimmerer, K.S. Biological diversity in agriculture and global change. Annu. Rev. Environ. Resour. 2010, 35, 137-166. [CrossRef]

52. Sultan, B.; Gaetani, M. Agriculture in West Africa in the twenty-first century: Climate change and impacts scenarios, and potential for adaptation. Front. Plant Sci. 2016, 7, 1-20. [CrossRef]

53. Santillán-Fernández, A.; Trejo Cabrera, M.; Martínez Sánchez, A.; Martínez Ángel, L.; Vásquez Bautista, N.; Mejía, S.L. Potencial productivo de Vanilla planifolia Jacks en el Totonacapan, México, mediante técnicas geográficas. Rev. Mex. Cienc. Agríc. 2019, 10, 789-802. [CrossRef]

54. Reyes-Hernández, H.; Trinidad-García, K.L.; Herrera-Cabrera, B.E. Caracterización del ambiente de los vainillales y área potencial para su cultivo en la Huasteca Potosina. Biotecnia 2018, 20, 49-57. [CrossRef]

55. Castelan-Culebro, F. Efecto de la temperatura sobre la germinación in vitro y crecimiento del tubo polínico en polen de Vanilla planifolia Jacks. ex Andrews (Orchidaceae). Bachelor's Thesis, Universidad Veracruzana, Xalapa, Veracruz, México, 2015. 
56. Trinidad García, K.L.; Reyes Hernández, H.; Martínez Salazar, R.I.; Galarza Rincón, E. Distribución de Vanilla planifolia Jacks. ex Andrews y acciones para su conservación en la Huasteca Potosina. Rev. Mex. Cienc. For. 2019, 10, 108-134. [CrossRef]

57. Barrera-Rodríguez, A.I.; Herrera-Cabrera, B.E.; Jaramillo-Villanueva, J.L.; Escobedo-Garrido, J.S.; Bustamante-González, Á. Caracterización de los sistemas de producción de vainilla (Vanilla planifolia A.) bajo naranjo y en malla sombra en el Totonacapan. Trop. Subtrop. Agroecosyst. 2009, 10, 199-212.

58. Hernández-Hernández, J. Mexican vanilla production. In Handbook of Vanilla Science and Technology, 2nd ed.; Havkin-Frenkel, D., Belanger, F.C., Eds.; Wiley-Blackwell: Hoboken, NJ, USA, 2019; pp. 3-25.

59. Schlüter, P.M.; Arenas, M.A.; Harris, S.A. Genetic variation in Vanilla planifolia (Orchidaceae). Econ. Bot. 2007, 61, 328. [CrossRef]

60. Secretaría de Agricultura, Ganadería, Desarrollo Rural, Pesca y Alimentación (SAGARPA). In Planeación Agrícola Nacional 2017-2030. Vainilla Mexicana; SAGARPA: Ciudad de México, México, 2017; pp. 1-11.

61. Borbolla-Pérez, V.; Iglesias-Andreu, L.G.; Luna-Rodríguez, M.; Octavio-Aguilar, P. Perceptions regarding the challenges and constraints faced by smallholder farmers of vanilla in Mexico. Environ. Dev. Sustain. 2017, 19, 2421-2441. [CrossRef]

62. De Guzman, C.C.; Zara, R.R. Vanilla. In Handbook of Herbs and Spices, 2nd ed.; Peter, K.V., Ed.; Woodhead Publishing: Cambridge, UK, 2012; Volume 1, pp. 547-590.

63. Montagnini, F. Función de los sistemas agroforestales en la adaptación y mitigación del cambio climático. In Sistemas Agroforestales: Funciones Productivas, Socioeconómicas y Ambientales, 1st ed.; Montagnini, F., Somarriba, E., Murgueitio, E., Fassola, H., Eibl, B., Eds.; CATIE-CIPAV: Cali, Colombia, 2015; pp. 269-298.

64. Rapidel, B.; Allinne, C.; Cerdán, C.; Meylan, L.; De Melo, E.; Filho, V.; Avelino, J. Efectos ecológicos y productivos del asocio de árboles de sombra con café en sistemas agroforestales. In Sistemas Agroforestales: Funciones Productivas, Socioeconómicas y Ambientales, 1st ed.; Montagnini, F., Somarriba, E., Murgueitio, E., Fassola, H., Eibl, B., Eds.; CATIE-CIPAV: Cali, Colombia, 2015 ; pp. 5-20.

65. Bory, S.; Grisoni, M.; Duval, M.F.; Besse, P. Biodiversity and preservation of vanilla: Present state of knowledge. Genet. Resour. Crop Evol. 2008, 55, 551-571. [CrossRef]

66. Herrera-Cabrera, B.E.; Salazar-Rojas, V.M.; Delgado-Alvarado, A.; Contreras, J.; Contreras, C.; Cervantes-Vargas, J. Use and conservation of Vanilla planifolia J. in the Totonacapan Region, México. Eur. J. Environ. Sci. 2012, 2, 43-50. [CrossRef]

67. López Paniagua, J.E.; Bolaños Méndez, M.; González Ríos, A. Conservación Comunitaria en la Chinantla. In Pasado Presente y Futuro de Áreas Voluntarias Para la Coservación; Grupo Mesófilo, Asociación Civil: Oaxaca, México, 2017.

68. Bray, D.B.; Duran, E.; Anta, S.; Martin, G.J.; Mondragon, F. A new conservation and development frontier community protected areas in Oaxaca Mexico. Curr. Conserv. 2008, 22, 7-8.

69. Secretaria del Bienestar. Programa Sembrando Vida. Available online: https://www.gob.mx/bienestar/acciones-y-programas/ programa-sembrando-vida (accessed on 17 November 2021).

70. Nicholls, C.I.; Henao, A.; Altieri, M.A. Agroecología y el diseño de sistemas agrícolas resilientes al cambio climático. Agroecología 2015, 10, 7-31. 